\title{
Departmental Engagement in Doctoral Professional Development: Lessons from Political Science
}

\author{
Loleen Berdahl \\ University of Saskatchewan \\ Jonathan Malloy \\ Carleton University
}

\begin{abstract}
There is widespread discussion about the need to develop and enhance the career prospects of PhD graduates, and many Canadian universities are seeking to provide professional development programs and mentorship specifically for doctoral students. This paper considers doctoral career preparation from the department level through an in-depth examination of how Canadian political science departments approach the issue, drawing on a survey of department chairs. We find that departments are supportive of professional development; while departments are not in the position to provide extensive programs and struggle to integrate efforts systematically, they are well-positioned to participate in collaborative approaches and welcome improved communication and coordination. We argue that graduate faculties should consult with departments and engage them in professional development program design, perhaps tailoring to specific disciplines as needed, and that departments should look for opportunities to work with graduate faculties before initiating their own programs.
\end{abstract}

\section{Résumé}

Cet article examine la préparation à la carrière des étudiants du doctorat au niveau des départements, à travers un examen approfondi de la façon dont les départements de sciences politiques canadiens abordent la question. Un 
sondage réalisé auprès des directeurs de département permet de constater que ceux-ci appuient le développement professionnel. Bien que les départements ne soient pas en mesure de fournir des programmes de préparation à la carrière de grande envergure et aient du mal à intégrer systématiquement les efforts, ils sont bien placés pour participer à des approches collaboratives et souhaitent une amélioration de la communication et de la coordination. Nous soutenons que les facultés d'études supérieures devraient consulter les départements et les faire participer à la conception de programmes de développement professionnel, en les adaptant éventuellement à certaines disciplines au besoin, et que les départements devraient rechercher les occasions de travailler avec les facultés d'études supérieures.

\section{Introduction}

There is widespread discussion about the need to develop and enhance the career prospects of Canada's PhD graduates. In 2014, the Canadian Journal of Higher Education devoted a special issue (Osborne et al., 2014) to the topic. It is the subject of numerous reports and studies (e.g., Edge \& Munro, 2015; Institute for Public Life of Arts and Ideas, 2013; Maldonado, Wiggers, \& Arnold, 2013) and a perennial topic of discussion among scholars (e.g, Aspenlieder \& Vander Kloet, 2014; Hewitt, 2018; Rooke, 2018). Similar discussions are found internationally (Council of Graduate Schools and Educational Testing Service, 2012; Denecke, Feaster \& Stone, 2017; Jackson \& Michelson 2014). While most PhDs eventually develop fulfilling careers whether inside or outside academia (Jonker, 2016; University of British Columbia, 2017; University of Toronto, 2018), they often experience a lengthy difficult period of adjustment (Acker \& Haque, 2017; Edge \& Munro, 2015; Etmanski et al., 2017; Statistics Canada, 2014). To address these concerns, many Canadian universities are seeking to provide and expand professional development programs for graduate students (Lypka \& Mota, 2017; Mota, 2017; Rose, 2012).

Existing scholarly research on $\mathrm{PhD}$ professional development focuses primarily on university and graduate faculty-level programming delivered to individual students, with less examination of the role of departments and programs. This, we suggest, is an area that needs attention as departmental engagement may be critical to the success of doctoral professional development. Departments serve as the main point of student contact and identity, with supervisors in particular playing a key role in doctoral students' lives; additionally, academic disciplines may have their own disciplinary norms and cultures that influence approaches and opportunities for professional development.

Universities are complex and decentralized organizations that frequently face challenges with central coordination and prioritization (Buzzelli \& Allison, 2017; Hearn, 1996). There is reason to assume that such issues come into play with respect to doctoral professional development. Indeed, communication issues between the university and unit levels has been identified as a challenge for graduate professional development programs in Canada (Turner, 2017). In this paper we consider the role of departments in doctoral professional development by exploring two questions:

1. What role do chairs see for departments in doctoral professional development? 
2. What challenges do chairs report for departmental engagement in doctoral professional development?

We answer these questions through an examination of the Canadian political science discipline. Our intensive focus on political science as a single discipline case study follows the key scholarship of teaching and learning (SoTL) principle of being grounded in context (Felten, 2013): our study is grounded in both the context of common disciplinary norms, and the specific, local context and experiences of individual units. Drawing on survey responses from all department chairs within Canada's PhD granting political science programs, we find that chairs see a departmental responsibility to be involved in professional development programming, and that they report a number of sporadic departmental efforts to do so-primarily with respect to academic career preparation. Chairs report a number of challenges to further departmental engagement, including limited information, expertise, and capacity.

Based on our analysis, we argue that universities must emphasize collaborative approaches to graduate professional development that incorporate rather than duplicate or bypass departmental and disciplinary efforts. While departments are not in the position to provide extensive programs and often struggle to integrate and systemize their efforts, they are positioned to be able to participate in collaborative approaches and act as crucial gatekeepers and signallers to supervisors and students. Moving forward, we suggest that graduate faculties increase engagement of departments in program design and delivery, with attention to disciplinary cultures and norms, while departments should look for opportunities to work with graduate faculties before initiating their own programs.

\section{Context}

The growing attention to doctoral professional development reflects contemporary employment challenges for Canada's PhD students. The number of Canadian PhD students has grown dramatically since 2000-2001 (Statistics Canada, 2016). However, Canada lags behind other countries in transferable career skills programming for graduate students (Organisation for Economic Cooperation and Development, 2012); while other countries have been effective at optimizing the economic contributions of PhDs (Annan, 2012; Charbonneau, 2011; Edge \& Munro, 2015), many Canadian PhD graduates face difficult periods of adjustment and temporary employment (Acker \& Haque, 2017; Edge \& Munro, 2015; Etmanski et al., 2017; Statistics Canada, 2014).

Part of the challenge is a disconnection between student career goals and employment market realities. The majority of doctoral students enter their programs with the goal of academic careers (Edge \& Munro, 2015; Maldonado, Wiggers, \& Arnold, 2013; Simon, 2016), yet less than a fifth of PhDs across all disciplines are employed as permanent academics (Edge \& Munro, 2015, p. 22; emergent data suggest further variations by discipline [University of British Columbia, 2017; University of Toronto, 2018] and institution [Albaugh, 2017]). While political science, the focus of our case study, is a discipline that presents readily apparent skills and linkages to non-academic career opportunities (e.g., government, international development, communications, electoral politics, public opinion research [Dion and Stephenson, 2017]), it too reflects the above challenges as much as other social science and humanities disciplines (American Political Science Association, 
2015; National Science Foundation, 2016a, 2016b; Canadian data not available).

There is widespread public policy discussion about the need to develop and enhance the career prospects of $\mathrm{PhD}$ graduates beyond tenure-track academic careers, particularly in the humanities and social sciences, including political science (see: Calvert, 2011; Cassuto, 2015; Council of Graduate Schools, 2012; Edge \& Munro, 2015; Galt, 2011; Hewitt, 2018; Institute for Public Life of Arts and Ideas, 2013; Jackson \& Michelson, 2014; Maldonado, Wiggers \& Arnold, 2013; Manathunga, Pitt, \& Critchley, 2009; Organisation for Economic Cooperation and Development, 2012; Polziehn, 2011). While some discussion focuses on restructuring doctoral education entirely (e.g., Canadian Association of Graduate Studies, 2016; Institute for Public Life of Arts and Ideas, 2013), the more dominant paradigm emphasizes new forms of $\mathrm{PhD}$ career mentorship for non-academic career paths, and university graduate faculties are devoting increasing resources to professional development programs (such as workshops to identify transferable skills) for graduate students (Lypka \& Mota, 2017; Mota, 2017). It is within this context that our study takes place.

\section{Literature}

A scholarly literature has emerged in response to the above-noted increase in $\mathrm{PhD}$ professional development programming. In this section, we briefly synthesize what is known to date, with specific note of the political science discipline, and identify two areas where further research is needed.

There is a scholarly literature of case studies, natural experiments, surveys and other research on preparation of PhDs and junior faculty for academic careers (Green \& Bauer, 1995; Kunselman et al., 2003; Lunsford, 2012; Paglis et al., 2006; Peno et al., 2016). In addition to focusing on academic career preparation, there is robust existing scholarly literature examining how mentorship of individual students plays a role in doctoral professional development (Green \& Bauer, 1995; Higgins and Kram, 2001; Kram, 1985; Lunsford, 2012; Paglis et al., 2006; Starr \& DeMartini, 2015).

These patterns are also found in the political science discipline specifically: there is a small but growing literature on professional development in political science doctoral programs, focused primarily on the development of skills for academic careers (for example, Pleschová \& Simon [2009] and Trepanier [2016] examine issues related to teacher-training in political science doctoral programs). Political science research to date also includes data collection on individual career outcomes (American Political Science Association, 2015, 2016; Harris, 2015; Hesli et al., 2006; Mann, 1998).

While the literature provides a useful foundation, there are two notable limitations to having a fulsome understanding of doctoral professional development: a scarcity of scholarly literature on non-academic career preparation, and limited consideration of organizational and structural contexts. Speaking to the first, literature on non-academic career preparation for PhDs, both in Canada and internationally, is largely applied rather than scholarly, in the form of policy reports and discussion papers (though see Osborne et al., 2014). Much non-academic career research is prescriptive and is rarely theoretically informed or driven, focusing on collections of data on graduate pathways and outcomes, best practices, and user satisfaction (Council of Graduate Schools, 2012; Edge \& Munro, 2015; Jonker, 2016; Lypka \& Mota, 2017; Mota, 2017; Rose, 2012; Sekuler et al., 
2013; Thouaille, 2017; University of British Columbia, 2017; University of Toronto, 2018; specific to political science, see American Political Science Association, 2016; Jasperson, 2006; Klarner, 2016; Lowenthal, 2012; Murakami, 2012).

The second limitation of research to date is the limited consideration of the institutional and organizational contexts within which mentoring and programming takes place (Chandler et al., 2016) or development of "mentoring cultures" (Sheridan et al., 2015). While the Canadian Association of Graduate Studies has increasingly turned attention to issues of assessing PhD professional development (Lypka \& Mota, 2017; Mota, 2017), there is as of yet little systematic study of institutional factors affecting the success and impact of $\mathrm{PhD}$ professional development initiatives, such as coordination, expertise, and resource distribution between different university units and levels (though see Holaday et al., 2007; Rose, 2012). While some studies of graduate career preparation recognize that "new structures for organizing information about careers are needed" (Council of Graduate Schools 2012, p. 28), the existing literature-whether scholarly or more prescriptive-offers little critical reflection or empirical evidence here. Factors affecting PhD career mentoring and programming such as organizational cultures, reward/motivation systems for mentors, competition for resources and priorities, and interdependence and interactions within universities have received limited research attention.

Universities and other educational organizations are "loosely coupled" with only limited interdependence between components, and limits to hierarchical and central power (Buzzelli \& Allison, 2017; Hearn, 1996; Orton and Weick, 1990; Weick, 1976). Academic units in particular operate with a high degree of decentralization and autonomy both externally and internally, with faculty accustomed to a high level of individual independence. This autonomy can both inhibit or enable coordination: while presenting challenges to central direction, its flexibility can also allow for quick adaptation and change (Hearn, 1996). Nevertheless, universities are normally "bottom heavy" (Buzzelli \& Allison, 2017) and academic units and faculty are accustomed to operating autonomously and do not automatically look to central actors and hierarchies for direction-especially in very decentralized and discipline-specific areas such as graduate programming.

Understanding the role of organizational factors and dynamics is thus critical if Canadian universities are to advance doctoral career mentorship. As Osborne et al. (2014) note, "Already the question of institutional responsibility and accountability echoes across these debates. Who is responsible for these reforms and how best should they be implemented?" (p. vi). The organizational structure of universities presents a conundrum for graduate professional programming. Academic departments have autonomy and primary responsibility for graduate academic programming, but limited expertise or resources for non-academic programming; graduate faculties have resources but insufficient direct access to doctoral programs and students themselves and limited authority to overcome this. Links to other units with expertise and knowledge such as career centres or alumni offices may be further complicated by different organizational relationships and reporting and resource hierarchies within universities (Despeaux, 2014). Moreover, professional development programming must compete with other important priorities for time, attention, and resources both in terms of institutional decisions and the personal engagement of key individuals such as supervisors, department chairs, and graduate deans.

Our research consequently focuses attention on the organizational dimensions of doc- 
toral mentorship and the opportunities and challenges it presents. Understanding the departmental perspective provides useful insights to how universities can best supply mentorship to students. It also allows us to identify barriers and challenges to doctoral mentorship beyond attitudinal resistance and reluctance to change. By answering two research questions-what role do chairs see for departments in doctoral professional development, and what challenges do chairs report for department engagement in doctoral professional development?-we shed important light on how doctoral career mentorship can be advanced in universities and better understood as a scholarly phenomenon.

\section{Methodology}

We examine our two research questions through analysis of an original online survey of Canadian political science department chairs. The online survey model is appropriate to our study as it was highly accessible to the respondents and it allowed for a mix of closed- and open-ended questions-an important advantage for issue identification given the exploratory nature of our research. We designed original quantitative and qualitative survey questions after conducting a review of existing literature. Once our survey draft was complete, we consulted with eight Canadian political science professors (including some former department chairs) to refine the questions. We then programmed the survey into Qualtrics software, and five additional political science professors pretested the survey, after which we refined the survey questions further for clarity. The research ethics boards of each co-investigator's university declared the survey exempt from standard review and approval processes. We administered the survey from August 17 to September 18, 2016.

Our population of study is chairs of Canada's 20 political science departments offering $\mathrm{PhD}$ programs. Department chairs are an ideal population of study due to their positions as organization leaders, rather than graduate chairs who may have more direct experience with graduate programs but less familiarity with the larger departmental and university context in which programs operate. Further, department chairs are individuals who are uniquely positioned to lead change at the unit level, as they possess considerable influence over the use of departmental resources and have the capacity to initiate important departmental conversations. While future study should examine perceptions of graduate chairs and other faculty, $\mathrm{PhD}$ students and recent $\mathrm{PhD}$ graduates, and actors at other organizational levels (such as graduate deans and professional development staff), we suggest that department chairs provide a useful starting point for documenting prevailing attitudes within programs and the potential for program innovation and change.

In the survey, we asked chairs questions focused on $\mathrm{PhD}$ career mentorship for academic and/or non-academic careers, including both formal training programs (for example, workshops and for-credit programs) and informal mentorship in the form of individualized and/or ad hoc career training (for example, a mock job talk). In closed-ended questions, we asked chairs to report on the formal and informal mentorship offered to $\mathrm{PhD}$ students in their units and at other university levels (graduate faculties, and/or university career centres), and to report their own opinions regarding the responsibility of departments and the university to provide such mentorship, including their perceptions of their department's capacity to do so. In open-ended questions, we invited chairs to reflect broadly on these topics. 
Our survey had a $100 \%$ response rate, making it a full population study $(\mathrm{N}=20)$ rather than a sample-based study, thereby removing respondent selection bias (a common limitation of online surveys) as an issue for our survey. At the same time, we do note a number of data limitations. First, chairs' opinions regarding the appropriate role for departments do not necessarily reflect those of other faculty members, including graduate chairs; for this reason, we clearly identify chair opinions as being individual, and do not imply such opinions are necessarily representative of entire departments. Second, it is possible that chairs are inaccurate in their reporting of departmental and/or university mentorship offerings; for this reason, we present such data as "offerings reported" rather than "offerings available". Third, while our focus on chairs allows for an understanding of how unit leaders perceive the issue of doctoral professional development, subsequent research is necessary to understand the perceptions of individuals at other university levels (such as deans, provosts and presidents).

\section{Findings: Roles for Departments}

Our first question asks: What role do chairs see for departments in doctoral professional development? Chairs report general agreement that departments should be involved, with support for departmental engagement being only slightly below that for university engagement (Table 1). At the same time, while the majority feel that departments have a responsibility to help students develop non-academic career skills, less than half agree that such training should be part of the curriculum.

Table 1. Attitudes Regarding Departmental and University Professional Development Roles

\begin{tabular}{|l|l|l|l|}
\hline & Agree & $\begin{array}{l}\text { Neither agree nor } \\
\text { disagree }\end{array}$ & Disagree \\
\hline $\begin{array}{l}\text { Graduate faculties should offer } \\
\text { career mentorship programs to } \\
\text { PhD students. }\end{array}$ & $\begin{array}{l}\text { Strongly 60\% } \\
\text { Somewhat 35\% }\end{array}$ & Neither 5\% & $\begin{array}{l}\text { Somewhat 0\% } \\
\text { Strongly 0\% }\end{array}$ \\
\hline $\begin{array}{l}\text { Departments should offer disci- } \\
\text { pline/ program-specific career } \\
\text { mentorship to PhD students. }\end{array}$ & $\begin{array}{l}\text { Strongly 45\% } \\
\text { Somewhat 35\% }\end{array}$ & Neither 10\% & $\begin{array}{l}\text { Somewhat 10\% } \\
\text { Strongly 0\% }\end{array}$ \\
\hline $\begin{array}{l}\text { Departments have a responsibil- } \\
\text { ity to help their PhD students } \\
\text { develop skills that can be used in } \\
\text { non-academic careers. }\end{array}$ & $\begin{array}{l}\text { Strongly 30\% } \\
\text { Somewhat 30\% }\end{array}$ & Neither 25\% & $\begin{array}{l}\text { Somewhat 5\% } \\
\text { Strongly 10\% }\end{array}$ \\
\hline $\begin{array}{l}\text { Departments should explicitly } \\
\text { build the development of skills } \\
\text { transferable to non-academic } \\
\text { careers, such as professional } \\
\text { writing and project management, } \\
\text { into the PhD curriculum. }\end{array}$ & $\begin{array}{l}\text { Strongly 10\% } \\
\text { Somewhat 40\% }\end{array}$ & Neither 10\% & $\begin{array}{l}\text { Somewhat 30\% } \\
\text { Strongly 10\% }\end{array}$ \\
\hline
\end{tabular}


The predominant chair opinion that departments should play a role in doctoral professional development is coupled with reports of existing departmental efforts. At the formal professional development programming level (see Table 2), chairs report a smattering of departmental engagement that coexists alongside university level activities. Chairs report that both the university and department levels are active in teacher training, while career skills programs are reported to be more concentrated at the university level. At an informal level, chairs report that their departments provide a number of individualized mentorship opportunities, with robust individual academic mentoring and less robust individual non-academic mentoring (see Table 3).

Table 2. University and Department Professional Development Reported Offerings

\begin{tabular}{|c|c|c|c|c|}
\hline & \multicolumn{2}{|c|}{ Other parts of university } & \multicolumn{2}{|l|}{ Department } \\
\hline & Report offered & $\begin{array}{l}\text { Don't know if } \\
\text { offered }\end{array}$ & Report offered & $\begin{array}{l}\text { Don't know if } \\
\text { offered }\end{array}$ \\
\hline \multicolumn{5}{|l|}{ Teacher training } \\
\hline $\begin{array}{l}\text { Non-credit teacher train- } \\
\text { ing }\end{array}$ & $95 \%$ & $0 \%$ & $40 \%$ & $0 \%$ \\
\hline For credit teacher training & $40 \%$ & $35 \%$ & $0 \%$ & $0 \%$ \\
\hline $\begin{array}{l}\text { Opportunities to teach } \\
\text { courses }\end{array}$ & $45 \%$ & $15 \%$ & $95 \%$ & $0 \%$ \\
\hline \multicolumn{5}{|l|}{ Career skills } \\
\hline $\begin{array}{l}\text { Non-credit career skills } \\
\text { workshops/short courses }\end{array}$ & $90 \%$ & $5 \%$ & $45 \%$ & $0 \%$ \\
\hline $\begin{array}{l}\text { For credit/certificate } \\
\text { career skills workshops/ } \\
\text { short courses }\end{array}$ & $45 \%$ & $15 \%$ & $5 \%$ & $0 \%$ \\
\hline \multicolumn{5}{|l|}{ Networking } \\
\hline $\begin{array}{l}\text { Panels/ networking op- } \\
\text { portunities with potential } \\
\text { employers outside aca- } \\
\text { demia }\end{array}$ & $35 \%$ & $40 \%$ & $5 \%$ & $10 \%$ \\
\hline $\begin{array}{l}\text { Panels/ networking op- } \\
\text { portunities with PhD } \\
\text { program alumni working } \\
\text { outside academia }\end{array}$ & $15 \%$ & $55 \%$ & $30 \%$ & $10 \%$ \\
\hline
\end{tabular}

Table 3. Chair Reporting of Individualized Support

\begin{tabular}{|l|l|}
\hline & Report Offered \\
\hline Advice on application materials for academic jobs & $95 \%$ \\
\hline Opportunity to conduct mock job talks and academic interviews & $90 \%$ \\
\hline Advice on application materials for non-academic jobs & $60 \%$ \\
\hline Opportunity to conduct mock non-academic job interviews & $30 \%$ \\
\hline
\end{tabular}


While chairs report that their departments are engaged in both formal and informal programs and individualized mentoring, they also report that such activities are often episodic. Stated one, "Most supervisors and/or other faculty will offer some sort of mentoring, but it varies considerably [emphasis added]". Another chair reported, "The Graduate Chair offers extensive advice and guidance to graduate students on an informal basis [emphasis added]. She also organizes periodic [emphasis added] workshops for professional development". In the words of a third chair, "this is more individual supervisors and $\mathrm{PhD}$ committees offering help rather than a departmental initiative per se".

Overall, the chairs support specific initiatives for PhD mentoring, with a majority specifically supporting mentoring for non-academic jobs. But they also report departmental prioritization of academic over non-academic mentoring, and in either case, a relatively ad hoc nature centred around individual actors. Further, many also report uncertainty about what programs are available at the university level.

\section{Findings: Challenges of Departmental Engagement}

Our second question asks: What challenges do chairs report for department engagement in doctoral professional development? Our results point to three areas linked to coordination and collaboration between different parts of the university: information, expertise, and capacity.

First, chairs are unclear about the specific mentorship needs of doctoral students. A number wrote that they do not know where PhDs end up working ("What jobs do PhD students get?"; "Information on where people end up with a $\mathrm{PhD}$ would be very helpful"). Some wrote that they require more information about the needs of potential employers ("It would be very helpful for us to know more from prospective non-academic employers [public sector, nongovernmental, corporate, advocacy, etc.] about what they would find most useful from prospective PhD level employees"; "a greater understanding of what types of skills and training non-academic employers would be looking for candidates to possess [is needed]"). Another information gap reported by chairs is what students themselves require ("What was or would be helpful to our [now employed] students in finding work/performing in the workplace? Would internships/professional development [outside the academy] be useful?"). As one chair wrote, such information is necessary for successful professional development program design, as it would allow efforts to "be tailored to the fields in which the newly minted PhDs will have the greatest chance of success and best fit with their doctoral work".

Second, chairs report limited confidence in the ability of their units to provide professional development due to a lack of internal expertise beyond academic careers (Table 4). Many chairs disagree that their faculty are equipped to help students, and many agree that supervisors feel less equipped to provide such mentorship. These perceptions are not surprising, given that faculty members generally have limited experience working directly outside academia. 
Table 4. Attitudes Regarding Departmental Expertise in Non-Academic Career Mentorship

\begin{tabular}{|l|l|l|l|}
\hline & Agree & $\begin{array}{l}\text { Neither agree nor } \\
\text { disagree }\end{array}$ & Disagree \\
\hline $\begin{array}{l}\text { Our faculty are well- } \\
\text { equipped to help PhD } \\
\text { students pursue non- } \\
\text { academic career paths. }\end{array}$ & $\begin{array}{l}\text { Strongly 5\% } \\
\text { Somewhat 15\% }\end{array}$ & Neither 25\% & $\begin{array}{l}\text { Somewhat 35\% } \\
\text { Strongly 20\% }\end{array}$ \\
\hline $\begin{array}{l}\text { Supervisors feel less } \\
\text { equipped to supervise } \\
\text { students who do not } \\
\text { plan to pursue an aca- } \\
\text { demic career. }\end{array}$ & $\begin{array}{l}\text { Strongly 10\% } \\
\text { Somewhat 45\% }\end{array}$ & Neither 0\% & $\begin{array}{l}\text { Somewhat 40\% } \\
\text { Strongly 5\% }\end{array}$ \\
\hline
\end{tabular}

Finally, chairs identified issues of departmental capacity to engage in doctoral professional development, and many express strong concerns about the university downloading onto departments. Stated one, "Although I agree that students need to be prepared for non-academic careers, most departments do not have the individual resources or faculty to train them in non-academic skills". Another wrote, "In most cases, individual departments are not resourceful enough to provide everything that $\mathrm{PhD}$ students need to prepare for careers". Due to such capacity concerns, some chairs suggested that professional development should be positioned in central units ("Don't download these responsibilities onto Departments. Centralize the teaching of non-discipline specific skills") rather than at the departmental level ("Provide general supports for training so that individual departments need not shoulder the burden of providing skill development").

The concerns about information gaps, limited expertise, and lack of capacity help to explain why, despite a general belief amongst the chairs that their departments have a role to play, departmental engagement is currently limited to a handful of activities, primarily around academic career mentorship, and primarily in an ad hoc fashion. The general desire to be positively engaged likely leads individual faculty (particularly graduate chairs) to try to create mentorship opportunities. However, without a strong understanding of student needs and lacking internal expertise and departmental capacity, such efforts are unsurprisingly episodic and limited in their ability to look beyond the academy. There exists, then, a tension: while departments may perceive a responsibility to be involved and a general desire to do so, they lack the ability to engage in a meaningful and sustained fashion.

What are the opportunities to allow departments to be more fully engaged in doctoral professional development while respecting their information, expertise and capacity limitations? Chairs point to increased communication and coordination within universities as part of the solution. First, chairs express a desire for greater departmental awareness of what activities are currently available to graduate students from the graduate faculty and other units, such as career service offices; one stated: "ensure units know what resources are available for their students", while another suggested that other parts of the university "maintain continuous communication with departments". Second, chairs suggest graduate faculties engage departments directly when they design professional development programs. One chair argued that "instead of defining those resources from 
top-down, [graduate faculties] need to go to the departments and find out what the needs are"; another suggested that graduate faculties "work more closely with units to coordinate efforts". There is a general desire for communication and coordination amongst university units - suggesting room for optimism moving forward.

\section{Discussion and Conclusion}

Our study found that despite awareness of the issue of PhD career outcomes and a general desire to contribute positively, there are key organizational challenges to doing so. While chairs are generally supportive of non-academic mentoring, they report concerns about the capacity of departments to supply programming that fills the gap between individualized mentoring by $\mathrm{PhD}$ supervisors and generalized programming by universities and graduate faculties. As our study focused on a single discipline, political science, the inclusion of the full population in our study allows our data to speak to the patterns within an entire national system, presenting a comprehensive overview of a national disciplinary system's practices. There is little reason to believe that the organizational realities of political science departments within universities differs from other disciplines, and we suggest that the lessons and implications of this study may be more broadly applicable. At the same time, consideration of other disciplines building off this research would be valuable, as disciplinary cultures and distinctive "communities of practice" (Austin, 2002; Brew, 2003; Gibbs et al., 2008; Umbach \& Porter, 2002), such as disciplinary norms regarding sole-investigator versus team approaches to research, can be expected to shape supervisory models and professional development programming at the departmental level (Lunsford, 2012).

At the practice level, our results suggest that universities should work to explicitly define roles and responsibilities; that graduate faculties rather than departments should take the lead on doctoral professional development; that faculties should seek to develop collaborative models that are responsive to disciplinary needs without creating demands on individual departments; and that departments should resist the temptation to create their own programs and instead seek to work with graduate faculties. To achieve these ends, graduate faculties should consult with departments about program design, to identify areas where programs should be tailored to specific disciplinary needs, and areas where more general programs are appropriate. Such practices may already be present in some universities. Graduate faculties should seek to create programs that draw upon expertise within departments, should it exist, without downloading responsibility to departments; this approach would expand the availability of expertise to students beyond individual departments while protecting sustainability. For example, a faculty member with expertise in public relations could participate in a graduate faculty workshop that is open to all doctoral students, opening the reach of the program while protecting the department from the organizational responsibilities. Graduate faculties should also create communications strategies to ensure that department chairs, graduate chairs, and supervisors are regularly informed about doctoral career mentorship programs and opportunities, both so that information can be passed along to students and so that departments do not begin to establish their own ad hoc initiatives under the assumption that programming is not available. Ongoing communication is also necessary given the regular rotation of these departmental responsibilities amongst faculty members. In the event that programs are 
in fact not available, we suggest that departments seek to work with graduate faculties to establish programs, rather than working alone.

At the research level, we suggest that there is considerable value in considering how organizational dynamics factor into doctoral professional development, particularly given that capacity and resources for professional development training are overwhelmingly housed in graduate faculties but graduate education itself is overwhelmingly concentrated in individual units and programs and concentrated around supervisor-student relationships. In this exploratory study, we considered the role of departments, the units with the most direct engagement with individual doctoral students, and we specifically focused on the perspectives of one of the key agents of change: department chairs. Expanding the research is a necessary next step. Of particular interest is the perspectives of graduate faculties themselves, including both deans and the professional staff who are seeking to work with students. Research should consider what opportunities and challenges they see in working collaboratively with departments and other units. Studying the perspective of graduate program chairs and faculty supervisors will also be valuable.

The considerable and growing attention to doctoral career preparation in Canada is well-placed. As Porter and Phelps wrote in the Canadian Journal of Higher Education:

Publicly funded institutions of higher learning have a responsibility to prepare scholars, to make a positive difference in society .... By remaining entrenched in traditional modes of education oriented solely towards preparation for the academy, we are failing to meet both our students' and society's expectations of how those who reach the pinnacle of formal education can contribute meaningfully to advancing the public good through a variety of career pathways. $(2014,55)$

The challenge for Canada's universities is how to work within existing organizational and institutional dynamics to best transition to more diversified career training for doctoral students. Understanding these organizational realities is necessary for progress to occur.

\section{References}

Acker, S., \& Haque, E. (2017). Left out in the academic field: Doctoral graduates deal with a decade of disappearing jobs. Canadian Journal of Higher Education, 47(3), 101119.

Albaugh, Q. M. (2017). The Americanization of Canadian political science? The doctoral training of Canadian political science faculty. Canadian Journal of Political Science, 5O(1), 243-262.

American Political Science Association. (2015). Six years of political science doctoral student placement, 2009-2014. Retrieved from http://www.apsanet. org/portals / 54/Files / DSP\%2oData/Data\%20 on\% 20the\%2oProfession/ SixYearsofPSDoctoralStudentPlacement_022315.pdf

American Political Science Association. (2016). Career profiles. Retrieved from http:// www.politicalsciencenow.com/category/career-paths/

Annan, R. (2012). Research internships and graduate education: How applied learning provides valuable professional skills and development for Canada's most highly 
trained students. Vancouver, BC: Mitacs and Canadian Association of Graduate Studies. Retrieved from https://www.mitacs.ca/sites/default/files/policy/Research_Internshipsand-Graduate-Education_October2012.pdf

Aspenlieder, E., \& Vander Kloet, M. (2014). Listen up! Be responsible! What graduate students hear about university teaching, graduate education and employment. Canadian Journal of Higher Education, 44(3), 20-38.

Austin, A. E. (2002). Preparing the next generation of faculty: Graduate school as socialization to the academic career. The Journal of Higher Education, 73(1), 94-122.

Brew, A. (2003). Teaching and research: New relationships and their implications for inquiry-based teaching and learning in higher education. Higher Education Research \& Development, 22(1), 3-18.

Buzzelli, M., \& Allison, D.J. (2017). Proposed strategic mandates for Ontario universities: An organizational theory perspective. Canadian Journal of Higher Education, 47(3), 170-191.

Calvert, K. (2011). Adaptive strategies for $\mathrm{PhD}$ candidates to a changing academic environment: Diversification and time management. Geographical Bulletin - Gamma Theta Upsilon, 52(2), 81-86.

Canadian Association of Graduate Studies. (2016). The doctoral dissertation purpose, content, structure, assessment. Retrieved from http://www.cags.ca/cagsdd/ documents/The\%20dissertation\%20-\%20consultation\%20document\%20FINAL\%20 ENG2.pdf

Cassuto, L. (2015). The graduate school mess: What caused it and how we can fix it. Cambridge, MA: Harvard University Press.

Chandler, D. E., Murphy, W. M., Kram, K. E., \& Higgins, M. C. (2016). Formal and informal mentoring: A developmental network perspective. In Peno, K. et al., (Eds.). Mentoring in formal and informal contexts (pp. 1-20). Charlotte, NC: Information Age Publishing.

Charbonneau, L. (2011, November 30). Is Canada producing too many PhDs? Yes, no and maybe. University Affairs. Retrieved from http://www.universityaffairs.ca/news/ news-article/is-canada-producing-too-many-phds

Council of Graduate Schools and Educational Testing Service. (2012). Pathways through graduate school and into careers. Report from the Commission on Pathways Through Graduate School and Into Careers. Princeton, NJ: Educational Testing Service.

Denecke, D., Feaster, K., \& Stone, K. (2017). Professional development: Shaping effective programs for STEM graduate students. Washington, DC: Council of Graduate Schools.

Despeaux, J. M., Gibbs, H. G., \& Schiff, J. S. (2014). The power of partnerships: Exploring the relationship between campus career centers and political science departments. Journal of Political Science Education, 1O(1), 37-47

Dion, M. L., \& Stephenson, L. (2017). Preparing for the future: methodology training in Canadian universities. Canadian Journal of Political Science, 5o(1), 281-294. 
Edge, J., \& Munro, D. (2015). Inside and outside the academy: Valuing and preparing PhDs for careers. Ottawa, ON: Conference Board of Canada.

Etmanski, B., Walters, D., \& Zarifa, D. (2017). Not what I expected: Early career prospects of doctoral graduates in academia. Canadian Journal of Higher Education, $47(3), 152-169$.

Felten, P. (2013). Principles of good practice in SoTL. Teaching \& Learning Inquiry: The ISSOTL Journal, 1(1), 121-125.

Galt, V. (2011, September 12). Professional development for grad students. University Affairs. Retrieved from http://www.universityaffairs.ca/features/feature-article/ professional-development-for-grad-students

Gibbs, G., Knapper, C., \& Piccinin, S. (2008). Disciplinary and contextually appropriate approaches to leadership of teaching in research-intensive academic departments in higher education. Higher Education Quarterly, 62(4), 416-436.

Green, S. G., \& Bauer, T. N. (1995). Supervisory mentoring by advisers: Relationships with doctoral student potential, productivity and commitment. Personnel Psychology, 48(3), 537-561.

Harris, C. (2015). Best practices in professional development in graduate education. In J. Ishkiyama, W. J. Miller \& E. Simon (Eds.), Handbook on teaching and learning in political science and international relations (pp. 35-46). London, UK: Edward Elgar.

Hearn, J.C. (1996). Transforming U.S. higher education: An organizational perspective. Innovative Higher Education, 21(2), 141-154.

Hesli, V. L., DeLaat, J., \& Youde, J. (2006). Success in graduate school and after: Survey results from the midwest region Part III. PS: Political Science \& Politics, 39(2), 1069-1088.

Hewitt, T. (2018, January 3). Underemployment of PhDs hurts research. The Chronicle-Herald. Retrieved from http://m.thechronicleherald.ca/business/1533598commentary-underemployment-of-phds-hurts-research

Higgins, M., \& Kram, K. (2001). Reconceptualizing mentoring at work: A developmental network perspective. The Academy of Management Review, 26(2) 264-288.

Holaday, B., Weaver, K. A., \& Nilson, L. B. (2007). Revisioning graduate professionaldevelopment programs. College Teaching, 55(3), 99-103.

Institute for the Public Life of Arts and Ideas. (2013). White paper on the future of the $P h D$ in the humanities. Montréal, QC: McGill University.

Jackson, D., \& Michelson, G. (2014). Factors influencing the employment of Australian $\mathrm{PhD}$ graduates. Studies in Higher Education, 4O(9), 1660-1678.

Jasperson, A. E. (2006). Under-explored opportunities: Insights into applied (vs. academic) career options in American politics. PS: Political Science \& Politics, 39(4), 952-953.

Jonker, L. (2016). Ontario's PhD graduates from 2009: Where are they now? Toronto, ON: Higher Education Quality Council of Ontario.

Klarner, C. (2016). Introduction: Beyond the ivory tower: political science careers 
outside academia. PS: Political Science and Politics, 49(3), 501-503.

Kram, K. E. (1985). Mentoring at work. Glenview, IL: Scott, Foresman.

Kunselman, J., Hensley, C., \& Tewksbury, R. (2003). Mentoring in academe: Models for facilitating academic development. Journal of Criminal Justice Education, 14(1), 1735 .

Lowenthal, A. F. (2012). Considering careers beyond academia: Advice for graduate students. PS: Political Science and Politics, 45(4), 810-811

Lunsford, L. (2012). Doctoral advising or mentoring? Effects on student outcomes. Mentoring \& Tutoring: Partnership in Learning, 2O(2), 251-270.

Lypka, C., \& Mota, M. H. R. (2017). Graduate professional development: Towards a national strategy: Phase 1. Prepared for the Canadian Association for Graduate Studies in conjunction with the Consortium of Canadian Graduate Student Professional Development Administrators. Retrieved from http://profdevprof.cags.ca/documents/ Phase1_English.FINAL.pdf

Maldonado, V., Wiggers, R., \& Arnold, C. (2013). So you want to earn a PhD? The attraction, realities, and outcomes. Toronto, ON: The Higher Education Quality Council of Ontario. Issue Paper No. 15: 1-41.

Manathunga, C., Pitt, R., \& Critchley, C. (2009). Graduate attribute development and employment outcomes: Tracking PhD graduates. Assessment \& Evaluation in Higher Education, 34(1), 91-103.

Mann, S. (1998). Finding jobs in political science: 1996 placement candidates report on their employment search and outcomes. PS: Political Science and Politics, 31(3), 591608.

Mota, M. H. R. (2017). Graduate professional development: Towards a national strategy: Phase 2. Prepared for the Canadian Association for Graduate Studies in conjunction with the Consortium of Canadian Graduate Student Professional Development Administrators. Retrieved from http://profdevprof.cags.ca/documents/Report\%20 2\%20_\%20October2017.pdf

Murakami, M. H. (2012). The broad value of a PhD in political science. PS: Political Science and Politics, 45(4), 812-814

National Science Foundation. (2016a). Table 13. Doctorate recipients, by subfield of study: 2005-15. Retrieved from https://nsf.gov/statistics/2017/nsf17306/data/tab13. pdf.

National Science Foundation. (2016b). Table 63. Statistical profile of postgraduation plans of doctorate recipients in psychology and social sciences fields, by sex and field of study: 2015. Retrieved from https://nsf.gov/statistics/2017/nsf17306/data/tab63.pdf

Organisation for Economic Cooperation and Development. (2012). Transferable Skills Training for Researchers: Supporting Career Development and Research. Paris, FR: OECD Publishing.

Orton, J. D. \& Weick, K. E. (1990). Loosely coupled systems: A reconceptualization. Academy of Management Review, 15(2), 203-23. 
Osborne, B. J., Carpenter, S., Burnett, M., Rofheiser, C., \& Korpan, C. (2014). Preparing graduate students for a world of work. Canadian Journal of Higher Education, 44(3), i-ix.

Paglis, L. L., Green, S. G., \& Bauer, T. N. (2006). Does advisor mentoring add value? A longitudinal study of mentoring and doctoral student outcomes. Research in Higher Education, 47(4), 451-476.

Peno, K., Mangiante, E. M. S., \& Kenahan, R. A., (Eds). (2016). Mentoring in formal and informal contexts. Charlotte, NC; Information Age Publishing.

Pleschová, G., \& Simon, Eszter. (2009). Teacher training for political science PhD students in Europe: Determinants of a tool for enhanced teaching higher education. Journal of Political Science Education, 5(3), 233-249.

Polziehn, R. (2011). Skills Expected from Graduate Students in Search of Employment in Academic and Non-Academic Settings. University of Alberta Faculty of Graduate Studies and Research. Retrieved from https://uofa.ualberta.ca/graduate-studies/-/ media/gradstudies/migrated-media/profdev/career/careerskillsexpected.pdf.

Porter, S. D., \& Phelps, J. M. (2014). Beyond skills: An integrative approach to doctoral student preparation for diverse careers. Canadian Journal of Higher Education, 44(3), $54-67$.

Rooke, A. (2018, February 15). Time to tackle the culture question in PhD programs. University Affairs. Retrieved from https://www.universityaffairs.ca/career-advice/ responsibilities-may-include/time-tackle-culture-question-phd-programs/

Rose, M. (2012). Graduate student professional development: A survey with recommendations. Ottawa, ON: Social Sciences and Humanities Research Council. Retrieved from http://www.sshrc-crsh.gc.ca/about-au_sujet/publications/SSHRC_ report_Graduate_Students_Professional_Skills_March_2012_eng.pdf

Sekuler, A. B., Crow, B., \& Annan, R. B. (2013). Beyond labs and libraries: Career pathways for doctoral students. Toronto, ON: Higher Education Quality Council of Ontario. http://www.heqco.ca/SiteCollectionDocuments/Beyond\%20Labs\%20and\%20 Libraries.pdf

Sheridan, L., Hubbard Murdoch, N., \& Harder, E. (2015). Assessing mentoring culture: Faculty and staff perceptions, gaps, and strengths. Canadian Journal of Higher Education, 45(4), 423-439.

Simon, L. (2016). Canadian graduate and professional student survey. Presentation to Canadian Association of Graduate Studies Annual Conference. Toronto, ON.

Starr, L. J. \& DeMartini, A. (2015). Addressing the needs of doctoral students as academic practitioners: A collaborative inquiry on teaching in higher education. Canadian Journal of Higher Education, 45(3), 68-83.

Statistics Canada. (2016). Cansim Table 477-0019 Postsecondary enrolments, by registration status, pan-Canadian standard classification of education (PCSCE), classification of instructional programs, primary grouping (CIP_PG), sex and student status. Retrieved from http://www5.statcan.gc.ca/cansim/a26?lang=eng\&id=4770019

Thouaille, M. A. (2017). One size does not fit all. Vitae. Retrieved from https://www. 
vitae.ac.uk/vitaepublications/reports/One\%20size\%2odoes\%2onot\%20fit\%20all\%20 -\%20report\%202017

Trepanier, L. (2017). SoTL as a subfield for political science graduate programs. Journal of Political Science Education, 13(2), 138-151.

Turner, J. (2017, October 10). Putting the "professional" in professional development. University Affairs. Retrieved from http://www.universityaffairs.ca/career-advice/ responsibilities-may-include/putting-professional-professional-development/

Umbach, P. D., \& Porter, S. R. (2002). How do academic departments impact student satisfaction? Understanding the contextual effects of departments. Research in Higher Education, 43(2), 209-234.

University of British Columbia. Faculty of Graduate and Postdoctoral Studies. (2017). UBC PhD career outcomes 2005-2013. Retrieved from http://outcomes.grad.ubc.ca/

University of Toronto. School of Graduate Studies. (2018). Employed and engaged: Career outcomes of our PhD graduates, 200O-2015. Retrieved from http://www.sgs. utoronto.ca/about/Pages/10,00o-PhDs-Project.aspx

Weick, K. E. (1976). Educational organizations as loosely coupled systems. Administrative Science Quarterly, 21(1), 1-19.

\section{Contact Information}

Loleen Berdahl, Professor

Department of Political Studies

University of Saskatchewan

Loleen.berdahl@usask.ca

Loleen Berdahl is Professor and Head in the Department of Political Studies at the University of Saskatchewan. Her research areas include Canadian political behaviour, public policy, and doctoral career development.

Jonathan Malloy is Professor in the Department of Political Science at Carleton University. His research areas include Canadian political institutions and career development processes in universities. 